Article

\title{
Preparation and Characterization of Multi-Doped Porous Carbon Nanofibers from Carbonization in Different Atmospheres and Their Oxygen Electrocatalytic Properties Research
}

\author{
Tao Wang ${ }^{1}$, Oluwafunmilola Ola ${ }^{2} \mathbb{D}$, Malcom Frimpong Dapaah ${ }^{3}$, Yuhao Lu ${ }^{1}$, Qijian Niu ${ }^{1, * \mathbb{D}}$, Liang Cheng ${ }^{3}$, \\ Nannan Wang ${ }^{4}$ (D) and Yanqiu Zhu ${ }^{4, *}$
}

check for updates

Citation: Wang, T.; Ola, O.; Dapaah, M.F.; Lu, Y.; Niu, Q.; Cheng, L.; Wang, N.; Zhu, Y. Preparation and Characterization of Multi-Doped Porous Carbon Nanofibers from Carbonization in Different Atmospheres and Their Oxygen Electrocatalytic Properties Research. Nanomaterials 2022, 12, 832. https://doi.org/10.3390/ nano12050832

Academic Editor:

Nikos Tagmatarchis

Received: 8 January 2022

Accepted: 25 February 2022

Published: 1 March 2022

Publisher's Note: MDPI stays neutral with regard to jurisdictional claims in published maps and institutional affiliations.

Copyright: (C) 2022 by the authors. Licensee MDPI, Basel, Switzerland. This article is an open access article distributed under the terms and conditions of the Creative Commons Attribution (CC BY) license (https:// creativecommons.org/licenses/by/ $4.0 /)$.
1 Key Laboratory of Modern Agriculture Equipment and Technology, School of Agricultural Engineering, Jiangsu University, Zhenjiang 212013, China; wangt073@163.com (T.W.); luyuhao1999@163.com (Y.L.)

2 Advanced Materials Research Group, University of Nottingham, Nottingham NG7 2RD, UK; Oluwafunmilola.ola1@nottingham.ac.uk

3 Institute of Environmental Health and Ecological Security, School of the Environment and SafetyEngineering, Jiangsu University, Zhenjiang 212013, China; 5103200301@stmail.ujs.edu.cn (M.F.D.); Clcheng@ujs.edu.cn (L.C.)

4 Guangxi Institute for Fullerene Technology, Key Laboratory of New Processing Technology for Nonferrous Metals and Materials, School of Resources Environment and Materials, University of Guangxi,

Nanning 530000, China; wangnannan@gxu.edu.cn

* Correspondence: niuqijian@ujs.edu.cn (Q.N.); y.zhu@gxu.edu.cn (Y.Z.)

\begin{abstract}
Recently, electrocatalysts for oxygen reduction reaction (ORR) as well as oxygen evolution reaction (OER) hinged on electrospun nanofiber composites have attracted wide research attention. Transition metal elements and heteroatomic doping are important methods used to enhance their catalytic performances. Lately, the construction of electrocatalysts based on metal-organic framework (MOF) electrospun nanofibers has become a research hotspot. In this work, nickel-cobalt zeolitic imidazolate frameworks with different molar ratios $\left(\mathrm{Ni}_{\mathrm{x}} \mathrm{Co}_{\mathrm{y}}-\mathrm{ZIFs}\right)$ were synthesized in an aqueous solution, followed by $\mathrm{Ni}_{\mathrm{x}} \mathrm{Co}_{\mathrm{y}}$-ZIFs/polyacrylonitrile (PAN) electrospun nanofiber precursors, which were prepared by a simple electrospinning method. Bimetal (Ni-Co) porous carbon nanofiber catalysts doped with nitrogen, oxygen, and sulfur elements were obtained at high-temperature carbonization treatment in different atmospheres (argon (Ar), Air, and hydrogen sulfide $\left(\mathrm{H}_{2} \mathrm{~S}\right)$ ), respectively. The morphological properties, structures, and composition were characterized by scanning electron microscopy (SEM), transmission electron microscopy (TEM), selected area electron diffraction (SAED), X-ray diffraction (XRD), and X-ray photoelectron spectroscopy (XPS). Moreover, the specific surface area of materials and their pore size distribution was characterized by Brunauer-Emmett-Teller (BET). Linear sweep voltammetry curves investigated catalyst performances towards oxygen reduction and evolution reactions. Importantly, $\mathrm{Ni}_{1} \mathrm{Co}_{2}-\mathrm{ZIFs} / \mathrm{PAN}-\mathrm{Ar}$ yielded the best ORR activity, whereas $\mathrm{Ni}_{1} \mathrm{Co}_{1}$-ZIFs/PAN-Air exhibited the best OER performance. This work provides significant guidance for the preparation and characterization of multi-doped porous carbon nanofibers carbonized in different atmospheres.
\end{abstract}

Keywords: electrospinning; porous carbon nanofibers; oxygen reduction reaction; oxygen evolution reaction

\section{Introduction}

Water splitting, metal-air batteries, and fuel cells are notable renewable energy technologies that rely heavily on oxygen reduction reaction (ORR) and oxygen evolution reaction (OER). Nonetheless, the slow kinetics of oxygen evolution and reduction reaction impedes their energy conversion efficiency [1]. Therefore, developing various oxygen 
reduction together with oxygen evolution catalysts is very important to improve their efficiencies. At present, $\mathrm{Pt} / \mathrm{C}$ and $\mathrm{RuO}_{2} / \mathrm{IrO}_{2}$ are the main commercial catalysts serving as ORR and OER catalysts [2,3]. However, they are both precious metal catalysts with a high price, low resource reserves, and low stability. In recent years, researchers have developed a variety of novel catalysts, mainly to reduce the use of precious metals to build non-precious metal catalysts. Among them, transition metal-carbon matrix composite catalysts have been widely studied. Many carbon-based materials (carbon nanoparticles [4], biochar [5], graphene [6], carbon nanotubes [7], carbon nanofiber [8], etc.) have become an important carrier for the construction of oxygen electrocatalysts because of their wide sources, being cheap and easy to obtain, their good electrical conductivity and diverse structures [9].


common approach for preparing these catalysts $[10,11]$. Moreover, the performance and functionalization of the catalysts were improved through single doping to multiple doping. Moreover, conversion between different forms of compounds from simple compounds to oxides [12], hydroxides [13], carbides [14], sulfides [15], phosphide [16], and their hybrids have achieved good catalytic performances.

Electrospinning is a novel technology for preparing one-dimensional nanofibers [17]. Electrospun nanofibers have been commonly utilized in many domains due to their merits, such as high void fraction, large specific surface area, large aspect ratio, and small diameter [18]. Recently, the construction of oxygen electrocatalysts based on electrospun nanofibers has attracted much attention [19]. Many electrospun nanofiber catalysts with different properties were prepared by transition metal and heteroatomic doping. The commonly used methods include direct pyrolysis of inorganic salts in electrospun nanofibers and in-situ surface growth of electrospun nanofibers. However, these methods tend to cause agglomeration of doped nanoparticles, or the preparation steps are relatively complicated. Metal-organic frameworks (MOFs) are crystalline materials fabricated by merging metal ions and organic ligands through coordination bonds [20-23]. A variety of highperformance oxygen electrocatalysts were prepared by changing the composition and carbonization conditions of MOF materials [24].

To date, some MOF-based composites have shown promising OER and ORR properties [25-27]. Further combination with electrospun nanofibers is beneficial for highly distributed active sites and porous carbon nanofiber catalysts preparation. The OER and ORR properties of bimetallic MOF electrospun structures show good dual-function performance [28]. However, carbonization of the same precursor in different atmospheres and conversion of different phases have not been reported. It is paramount to study the structure, composition, and properties of catalytic materials under different carbonization atmospheres for high-performance catalyst development.

Herein we report, for the first time, the assessment of bi-metal (nickel-cobalt) zeolitic imidazolate frameworks (NiCo-ZIFs) electrospun carbon nanofibers under three different atmospheres in one work. The different molar ratios of the bimetallic nanocrystal materials $\left(\mathrm{Ni}_{\mathrm{x}} \mathrm{Co}_{\mathrm{y}}-\mathrm{ZIFs}\right)$ were synthesized in an aqueous solution, and then $\mathrm{Ni}_{\mathrm{x}} \mathrm{Co}_{\mathrm{y}^{-}}$ ZIFs / polyacrylonitrile (PAN) nanofiber precursors were prepared by simple electrospinning method. Afterwards, the multi-doped porous carbon nanofiber catalysts for OER and ORR were obtained by carbonization in different atmospheres (Ar, Air, and $\mathrm{H}_{2} \mathrm{~S}$ ). The morphologies, structures, crystal compositions, and elemental compositions of the precursors and derived catalysts after carbonization were characterized. Finally, the OER and ORR catalytic effects of various samples under different conditions were investigated.

\section{Experimental Section}

\subsection{Materials}

Ethanol ( $\geq 99.7 \%), \mathrm{N}, \mathrm{N}$-dimethylformamide (DMF, $\geq 99.5 \%), \mathrm{Co}\left(\mathrm{NO}_{3}\right)_{2} \cdot 6 \mathrm{H}_{2} \mathrm{O}(99 \%)$, potassium hydroxide $(\mathrm{KOH}, 98 \%), \mathrm{Ni}\left(\mathrm{NO}_{3}\right)_{2} \cdot 6 \mathrm{H}_{2} \mathrm{O}(98 \%)$, polyacrylonitrile (PAN, molecular weight of $\left.150 \mathrm{Kg} . \mathrm{mol}^{-1}\right)$, and 2-methylimidazole $\left(\mathrm{C}_{4} \mathrm{H}_{6} \mathrm{~N}_{2}, \mathrm{MIM}\right)$ were obtained from Aladdin Biochemical Technology Co., Ltd. (Shanghai, China). DuPont Co. supplied the 
Nafion solution ( $5 \mathrm{wt} \%)$. The purchased chemicals were utilized as received without additional purification unless specified in this work.

\subsection{Preparation of Bimetal $\mathrm{Ni}_{x} \mathrm{Co}_{y}$-ZIFs Nanocrystals}

$\mathrm{Ni}_{\mathrm{x}} \mathrm{Co}_{\mathrm{y}}$-ZIFs nanocrystals were prepared by adding various molar ratios $(1,2$, and $4 \mathrm{mmol})$ of $\mathrm{Ni}\left(\mathrm{NO}_{3}\right)_{2} \cdot 6 \mathrm{H}_{2} \mathrm{O}$ and $\mathrm{Co}\left(\mathrm{NO}_{3}\right)_{2} \cdot 6 \mathrm{H}_{2} \mathrm{O}(4 \mathrm{mmol})$ to 2-methylimidazole $(300 \mathrm{mmol})$ aqueous

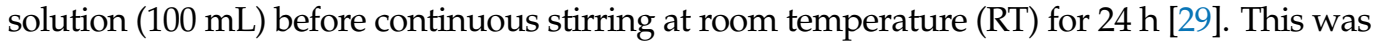
accompanied by 10 min centrifugation and rinsing thrice with deionized (DI) water. $\mathrm{Ni}_{\mathrm{x}} \mathrm{Co}_{\mathrm{y}}$ ZIFs powders were obtained, with $x$ and $y$ representing $n(N i) / n(C o)$ molar ratio.

\subsection{Preparation of Bimetal NixCoy-ZIFs/PAN Nanofibers}

$1.0 \mathrm{~g}$ of as-prepared $\mathrm{Ni}_{\mathrm{x}} \mathrm{Co}_{\mathrm{y}}$-ZIFs nanoparticles, $0.5 \mathrm{~g}$ of PAN polymer, and $4.5 \mathrm{~g}$ of DMF solvent were mixed to prepare the electrospinning solution after stirring for several hours. The obtained mixture was transferred to a plastic syringe $(5.0 \mathrm{~mL})$ with a single nozzle (stainless steel) of $0.6 \mathrm{~mm}$ diameter. For the typical electrospinning procedure, the applied high voltage with set interval between the collector (aluminum foil) and tip were $20 \mathrm{kV}$ and $15 \mathrm{~cm}$, respectively. Moreover, the syringe injection speed was $0.6 \mathrm{~mL} \cdot \mathrm{h}^{-1}$. After electrospinning, nanofibers from the aluminum foil were placed in a vacuum oven set to $80{ }^{\circ} \mathrm{C}$ overnight for residual solvent removal [30].

\subsection{Preparation of Multi-Doped Porous Carbon Nanofibers}

The dried $\mathrm{Ni}_{\mathrm{x}} \mathrm{Co}_{\mathrm{y}}-\mathrm{ZIFs} / \mathrm{PAN}$ nanofibers were heated in different atmospheres in a tube furnace. Three main cases were considered; (i) in Ar atmosphere: the $\mathrm{Ni}_{\mathrm{x}} \mathrm{Co}_{\mathrm{y}}-\mathrm{ZIFs} / \mathrm{PAN}$ precursor was heated at $800{ }^{\circ} \mathrm{C}$ for $2 \mathrm{~h}$ with $5^{\circ} \mathrm{C}$. $\mathrm{min}^{-1}$ heating rate, before cooling to room temperature; (ii) in Air atmosphere: after a carbonization process consistent with Ar atmosphere, the oxidation process was completed by heating for $2 \mathrm{~h}$ at $300^{\circ} \mathrm{C}$ in an Air atmosphere with $5{ }^{\circ} \mathrm{C}$. in $^{-1}$ heating rate; (iii) in $\mathrm{H}_{2} \mathrm{~S}$ atmosphere: during a carbonization process consistent with Ar atmosphere, the sulfurization process was initiated when the temperature rose to $800{ }^{\circ} \mathrm{C}$, and $\mathrm{H}_{2} \mathrm{~S}$ gas was supplied at this temperature for $2 \mathrm{~h}$ continuously.

\subsection{Material Characterization}

The morphological features of the synthesized catalysts were characterized by scanning electron microscopy (SEM) (JSM-6701F, JEOL, Tokyo, Japan) and transmission electron microscopy (TEM) (Tecnai G2 20 S-T win, FEI, Hillsboro, United States). The crystal structures were characterized with a D8 Advance X-ray diffraction (XRD) unit with $\mathrm{Cu}$ $\mathrm{K} \alpha$ radiation (Bruker, Billerica, United States ). Elemental composition and doping state were characterized by an ESCLAB 250 X-ray photoelectron spectroscopy (XPS) (Thermo Fischer Scientific, Massachusetts, USA). Pore size distribution and corresponding BrunauerEmmett-Teller (BET) surface area were characterized using an Autosorb-iQ gas sorptometer (Quantachrome, Florida, USA) by the standard volumetric procedure [31].

\subsection{Electrochemical Measurements}

For electrochemical performance measurements in the prepared samples, all were done in a conventional three-electrode system (CHI 660C and 760E, Chenhua, Shanghai, China), in which a Pt wire, an $\mathrm{Ag} / \mathrm{AgCl}$ electrode ( $3.0 \mathrm{M} \mathrm{KCl}$ solution), and a GCE (glassy carbon electrode, $\mathrm{d}=4.0 \mathrm{~mm}$ ) functioned as the counter electrode, reference electrode, and the working electrode, respectively. For ORR and OER, $0.1 \mathrm{~mol} \cdot \mathrm{L}^{-1}$ and $1.0 \mathrm{~mol} \cdot \mathrm{L}^{-1} \mathrm{KOH}$ aqueous electrolytes at $25^{\circ} \mathrm{C}$ were used. On catalyst ink synthesis, the catalyst $(5.0 \mathrm{mg})$ was distributed in a water/ethanol $(v / v=4: 1)$ solution $(1.0 \mathrm{~mL})$ with added Nafion solution $(5.0 \mathrm{wt} \%, 5.0 \mu \mathrm{L})$ using ultrasonication for $0.5 \mathrm{~h}$. Afterward, catalyst ink $(5.0 \mu \mathrm{L})$ was spread onto the working electrode surface for further electrochemical measurements. The catalytic activities of OER and ORR were characterized by linear sweep voltammetry (LSV) curves set at $10 \mathrm{mV} \cdot \mathrm{s}^{-1}$ scan rates [32]. A homemade $\mathrm{Zn}$-air battery was fabricated to examine the potential-current polarization curves [30]. The experiments were done in triplicates. 


\section{Results and Discussions}

The micro-morphologies of synthesized bimetallic $\mathrm{Ni}_{x} \mathrm{Co}_{y}-\mathrm{ZIFs}$ and the $\mathrm{Ni}_{\mathrm{x}} \mathrm{Co}_{\mathrm{y}}-$ ZIFs/PAN nanofiber precursors were characterized by SEM images, as depicted in Figure 1. From Figure $1 \mathrm{a}-\mathrm{c}$, the bimetallic $\mathrm{Ni}_{\mathrm{x}} \mathrm{Co}_{\mathrm{y}}$-ZIFs appeared in the form of nanoparticles. With the increase of $\mathrm{Co}$ ratio, the morphology of nanoparticles became smaller as the diameter gradually decreased from Figure $1 \mathrm{a}-\mathrm{c}$. As shown in Figure $1 \mathrm{~d}-\mathrm{f}$, the $\mathrm{Ni}_{\mathrm{x}} \mathrm{Co}_{\mathrm{y}}-\mathrm{ZIFs} / \mathrm{PAN}$ nanofibers had one-dimensional structures, with $\mathrm{Ni}_{x} \mathrm{Co}_{y}$-ZIFs convex-like crystals coating its surface. In Figure $1 \mathrm{f}$, the diameters of $\mathrm{Ni}_{1} \mathrm{Co}_{4}-\mathrm{ZIFs} / \mathrm{PAN}$ nanofibers were more uniform due to the small diameter of the coated $\mathrm{Ni}_{1} \mathrm{Co}_{4}$-ZIFs particles.
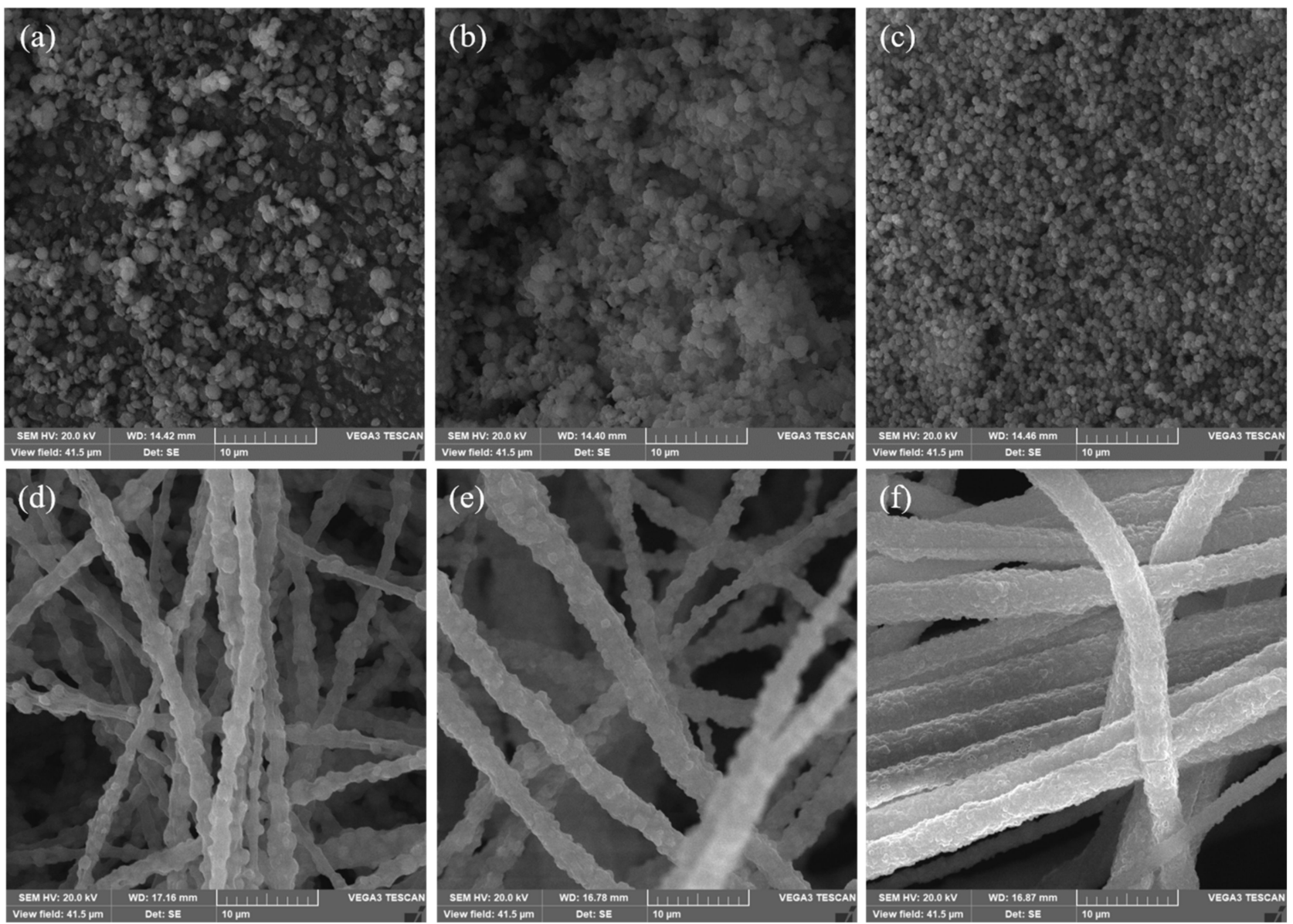

Figure 1. The SEM images of the prepared nickel-cobalt zeolitic imidazolate frameworks $\left(\mathrm{Ni}_{\mathrm{x}} \mathrm{Co}_{\mathrm{y}}-\mathrm{ZIFs}\right.$ ) crystals and $\mathrm{Ni}_{\mathrm{x}} \mathrm{Co}_{\mathrm{y}}-\mathrm{ZIFs} /$ polyacrylonitrile (PAN) nanofibers at various molar ratios: (a) $\mathrm{Ni}_{1} \mathrm{Co}_{1}$-ZIFs; (b) $\mathrm{Ni}_{1} \mathrm{Co}_{2}$-ZIFs; (c) $\mathrm{Ni}_{1} \mathrm{Co}_{4}$-ZIFs; (d) $\mathrm{Ni}_{1} \mathrm{Co}_{1}$-ZIFs /PAN; (e) $\mathrm{Ni}_{1} \mathrm{Co}_{2}-\mathrm{ZIFs} / \mathrm{PAN}$; (f) $\mathrm{Ni}_{1} \mathrm{Co}_{4}$-ZIFs/PAN nanofibers.

The crystal structure of the synthesized bimetallic $\mathrm{Ni}_{x} \mathrm{Co}_{\mathrm{y}}$-ZIFs nanoparticles was characterized by XRD patterns illustrated in Figure 2. With the increase of Ni content, the crystal structure gradually disappeared. However, the crystal structure of $\mathrm{Ni}_{1} \mathrm{Co}_{4}$-ZIFs was the same as the Co-ZIFs. This was in consent with already reported works [29].

The content and distribution of various elements in the synthesized bimetallic $\mathrm{Ni}_{\mathrm{x}} \mathrm{Co}_{\mathrm{y}}-$ ZIFs nanoparticles were studied by TEM elemental mappings in Figure 3. The contents of $\mathrm{C}, \mathrm{N}$, and $\mathrm{O}$ elements in bimetallic $\mathrm{Ni}_{\mathrm{x}} \mathrm{Co}_{\mathrm{y}}$-ZIFs crystals had no significant difference. However, the proportion of $\mathrm{Ni}$ and $\mathrm{Co}$ was quite different. In $\mathrm{Ni}_{1} \mathrm{Co}_{1}$-ZIFs crystals, the $\mathrm{Ni}$ :Co ratio was close to the theoretical value. However, in $\mathrm{Ni}_{1} \mathrm{Co}_{2}$-ZIFs and $\mathrm{Ni}_{1} \mathrm{Co}_{4}$-ZIFs samples, the doping ratio of $\mathrm{Ni}$ was far lower than the theoretical value, though the content was similar. Combined with XRD patterns, it was proven that Ni doping would affect the 
crystal stability, and $\mathrm{Ni}$ ions could hardly enter the crystal skeleton when the content of Co ions was high.

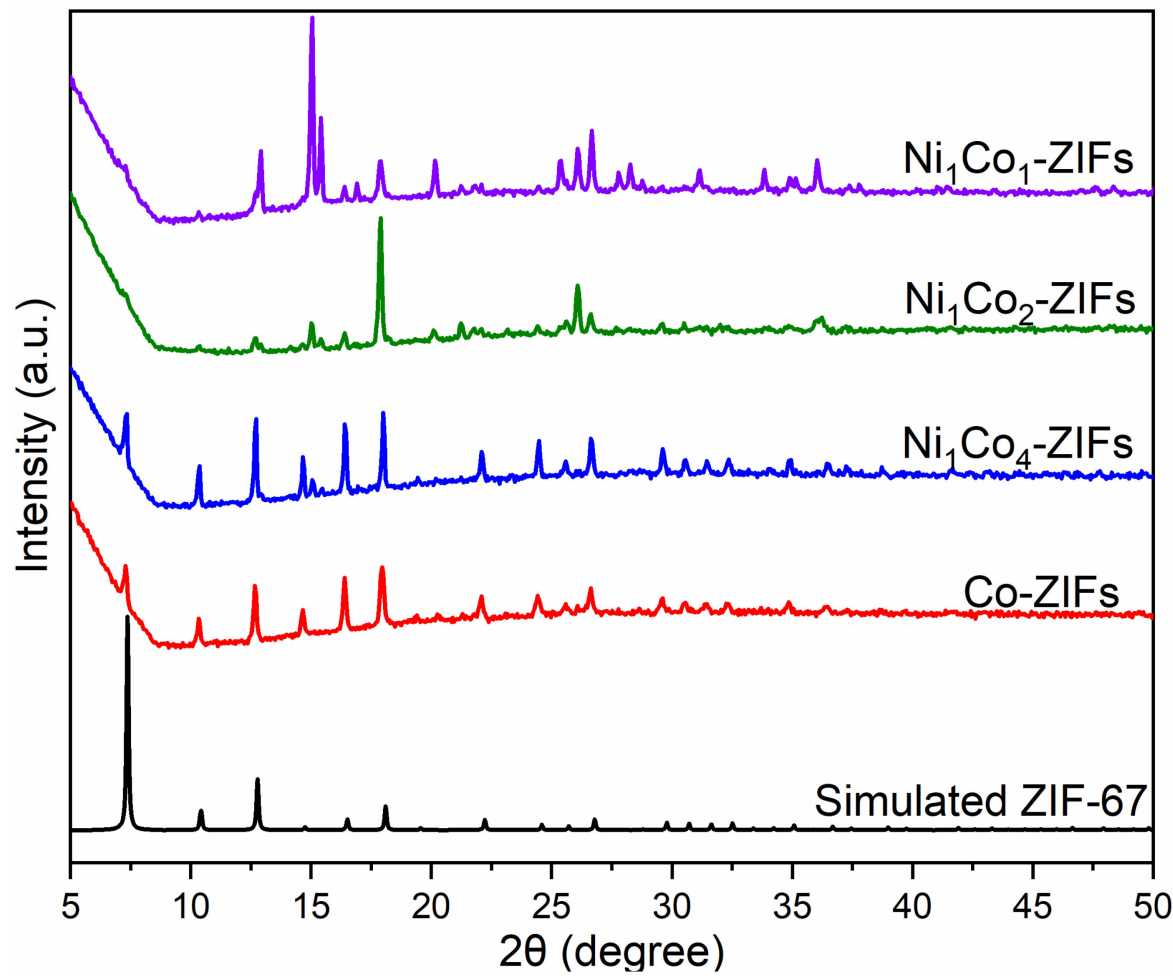

Figure 2. The XRD patterns of different $\mathrm{Ni}_{x} \mathrm{Co}_{y}-\mathrm{ZIFs}$ crystals: $\mathrm{Ni}_{1} \mathrm{Co}_{1}-\mathrm{ZIFs} ; \mathrm{Ni}_{1} \mathrm{Co}_{2}-\mathrm{ZIFs} ; \mathrm{Ni}_{1} \mathrm{Co}_{4}{ }^{-}$ ZIFs, and Co-ZIFs.
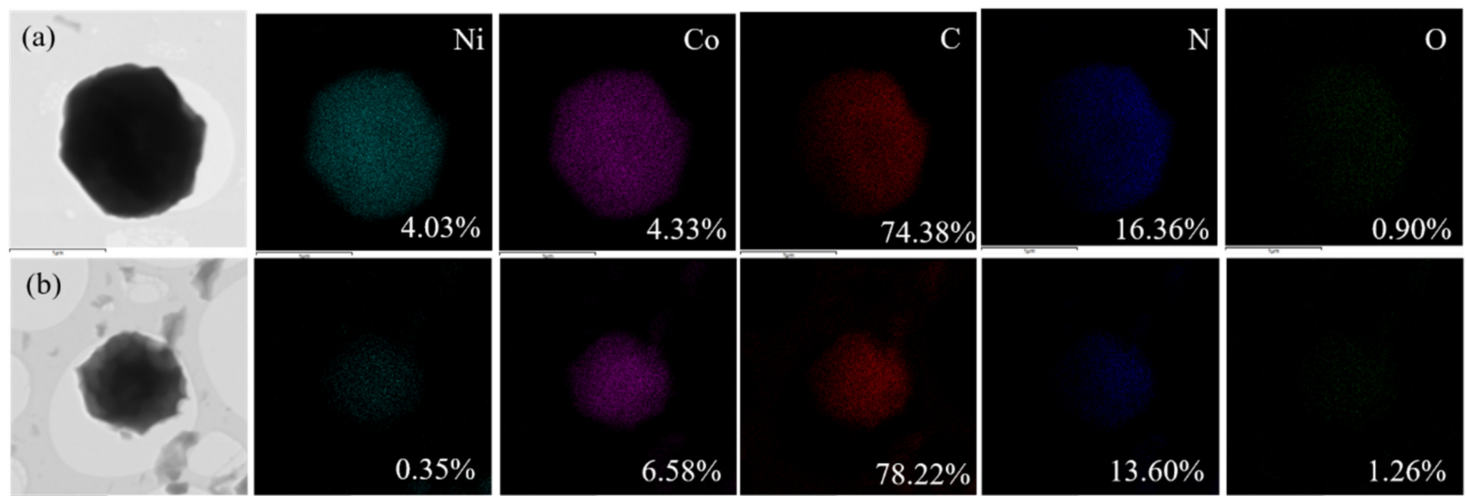

(c)
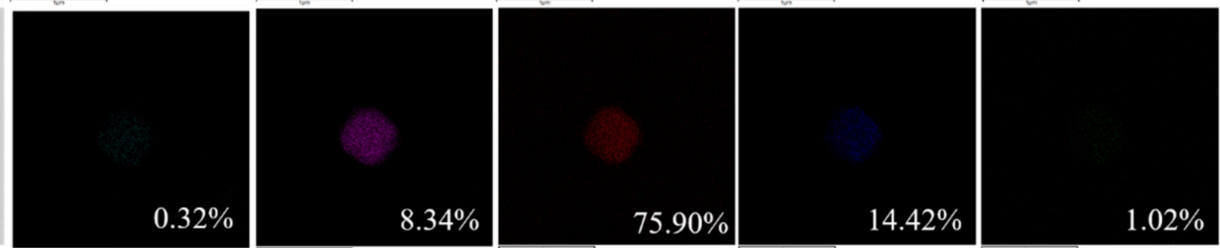

Figure 3. The TEM images and different elemental mappings of $\mathrm{Ni}_{\mathrm{x}} \mathrm{Co}_{\mathrm{y}}$-ZIFs crystals: (a) $\mathrm{Ni}_{1} \mathrm{Co}_{1}$ ZIFs; (b) $\mathrm{Ni}_{1} \mathrm{Co}_{2}$-ZIFs; (c) $\mathrm{Ni}_{1} \mathrm{Co}_{4}$-ZIFs.

The microstructures of the varied samples under different atmosphere carbonization were characterized by SEM images shown in Figure 4. The nanofiber samples that were carbonized in Ar atmosphere maintained the rough surface morphology. After carbonization in Air, some nanofibers were found to be broken. During the carbonization process, the morphology of the nanofibers was the same as those under Ar gas after the sulfurization 
process. The results showed that the oxidation process after carbonization easily led to the destruction of the overall structure of the nanofiber. In contrast, the general morphology of the nanofiber did not change significantly during the carbonization process under the protection of inert Ar gas.
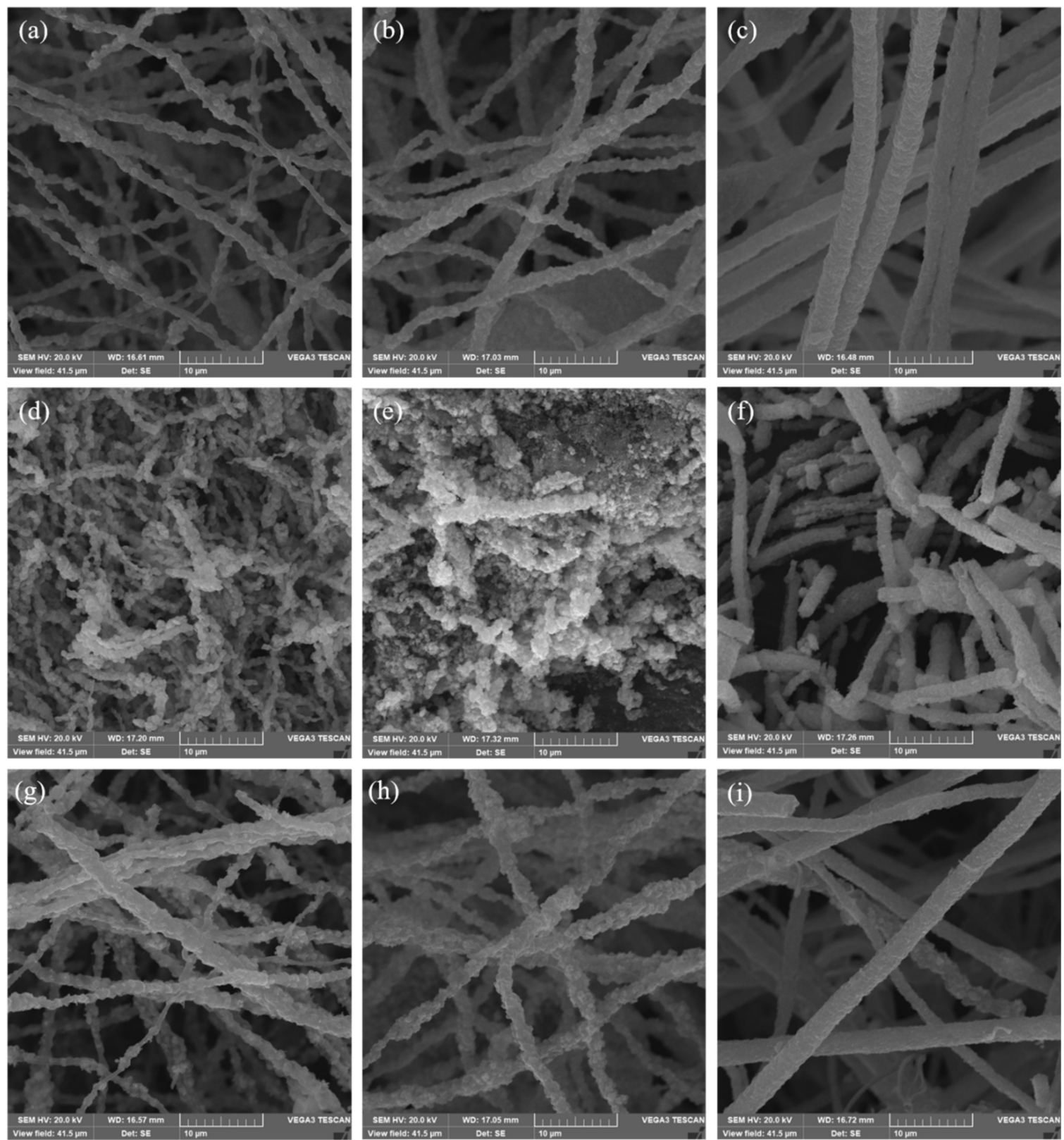

Figure 4. The SEM images of multi-doped porous carbon nanofibers derived from different $\mathrm{Ni}_{\mathrm{x}} \mathrm{Co}_{\mathrm{y}}{ }^{-}$ ZIFs/PAN nanofibers by carbonization, oxidation, and sulfurization in different atmospheres (Ar, Air, and $\mathrm{H}_{2} \mathrm{~S}$ ): (a) $\mathrm{Ni}_{1} \mathrm{Co}_{1}$-ZIFs / PAN-Ar, (b) $\mathrm{Ni}_{1} \mathrm{Co}_{2}$-ZIFs/PAN-Ar, (c) $\mathrm{Ni}_{1} \mathrm{Co}_{4}$-ZIFs/PAN-Ar; (d) $\mathrm{Ni}_{1} \mathrm{Co}_{1}$ ZIFs /PAN-Air, (e) $\mathrm{Ni}_{1} \mathrm{Co}_{2}$-ZIFs/PAN-Air, (f) $\mathrm{Ni}_{1} \mathrm{Co}_{4}$-ZIFs/PAN-Air; (g) $\mathrm{Ni}_{1} \mathrm{Co}_{1}$-ZIFs $/$ PAN-H $\mathrm{S}_{2}$, (h) $\mathrm{Ni}_{1} \mathrm{Co}_{2}$-ZIFs/PAN- $\mathrm{H}_{2} \mathrm{~S}$, (i) $\mathrm{Ni}_{1} \mathrm{Co}_{4}$-ZIFs/PAN- $\mathrm{H}_{2} \mathrm{~S}$.

The internal structure of carbonized samples was additionally characterized by TEM images, as displayed in Figure 5. Many metal nanoparticles were observed on nanofibers after carbonization in Ar atmosphere (Figure 5a-c). Before carbonization, the outline of the $\mathrm{Ni}_{\mathrm{x}} \mathrm{Co}_{\mathrm{y}}$-ZIFs crystals was much prominent. The nanoparticles derived from $\mathrm{Ni}_{1} \mathrm{Co}_{4}{ }^{-}$ ZIFs/PAN precursors were relatively small and uniform. After oxidation in Air, the derived nanoparticles became larger, and some nanofibers broke (Figure $5 \mathrm{~d}-\mathrm{f}$ ). The obtained results 
were coherent with the SEM images. After the sulfurization process, agglomeration of nanoparticles occurred. However, the morphology and distinct pore structure were still maintained (Figure 5g-i). From the crystal diffraction pattern (Figure 5 inserted), it was observed that the samples obtained by carbonization in different atmospheres had good crystal structure, among which the crystal diffraction ring structure after oxidation was the most distinct. At the same time, the catalysts derived from $\mathrm{Ni}_{1} \mathrm{Co}_{4}$-ZIFs/PAN had uniform nanoparticle doping and a complete nanofiber structure.
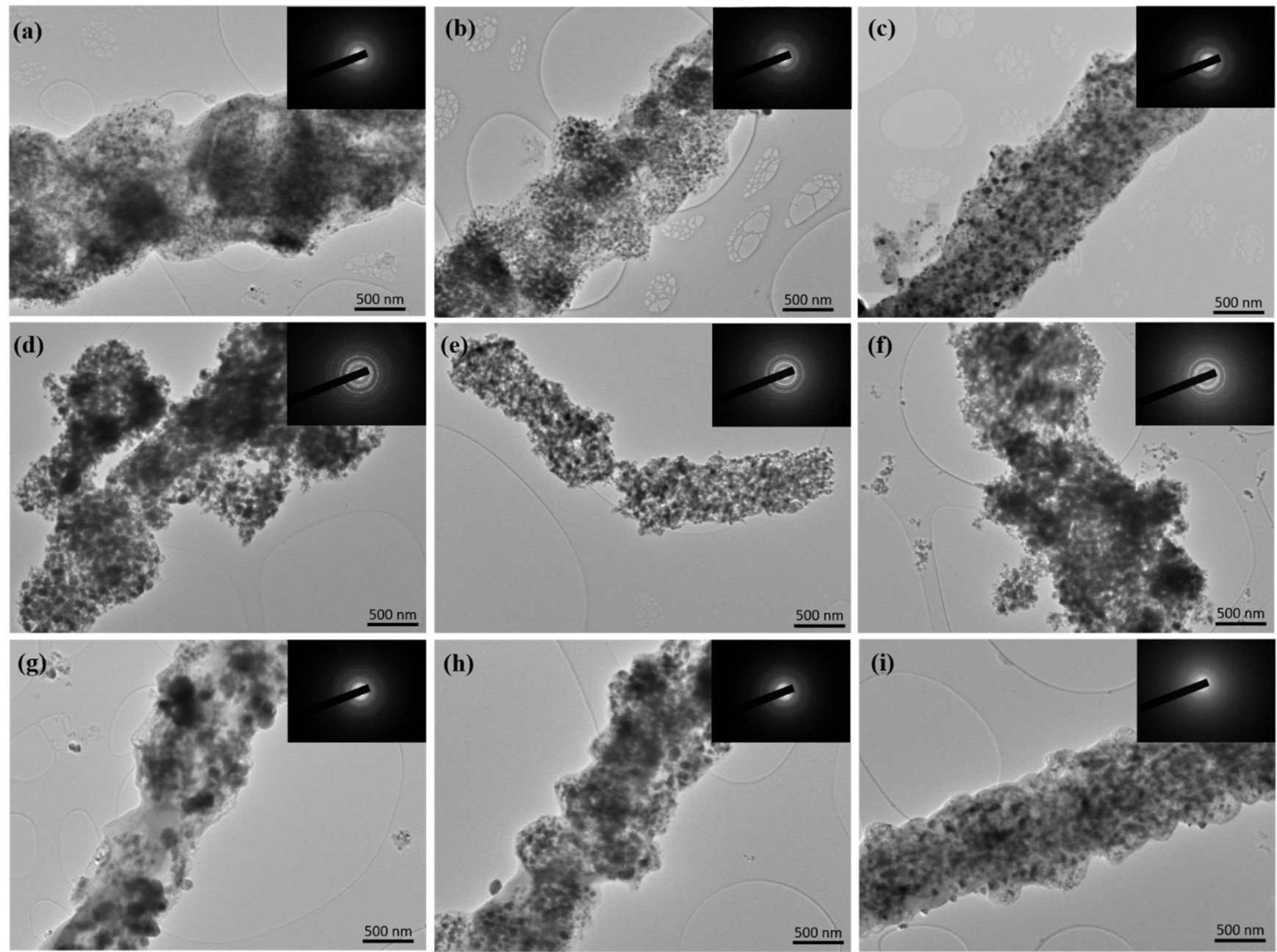

Figure 5. The TEM images of multi-doped porous carbon nanofibers derived from different $\mathrm{Ni}_{\mathrm{x}} \mathrm{Co}_{\mathrm{y}^{-}}$ ZIFs/PAN nanofibers by carbonization, oxidation and sulfurization in different atmospheres (Ar, Air, and $\mathrm{H}_{2} \mathrm{~S}$ ): (a) $\mathrm{Ni}_{1} \mathrm{Co}_{1}$-ZIFs/PAN-Ar, (b) $\mathrm{Ni}_{1} \mathrm{Co}_{2}$-ZIFs/PAN-Ar, (c) $\mathrm{Ni}_{1} \mathrm{Co}_{4}$-ZIFs/PAN-Ar; (d) $\mathrm{Ni}_{1} \mathrm{Co}_{1}$-ZIFs/PAN-Air, (e) $\mathrm{Ni}_{1} \mathrm{Co}_{2}$-ZIFs/PAN-Air, (f) $\mathrm{Ni}_{1} \mathrm{Co}_{4}$-ZIFs/PAN-Air; (g) $\mathrm{Ni}_{1} \mathrm{Co}_{1}$-ZIFs/PAN$\mathrm{H}_{2} \mathrm{~S}$, (h) $\mathrm{Ni}_{1} \mathrm{Co}_{2}$-ZIFs / PAN- $\mathrm{H}_{2} \mathrm{~S}$, (i) $\mathrm{Ni}_{1} \mathrm{Co}_{4}$-ZIFs / PAN- $\mathrm{H}_{2} \mathrm{~S}$.

Furthermore, the TEM images and elemental mappings of multi-doped porous carbon nanofibers derived from $\mathrm{Ni}_{1} \mathrm{Co}_{4}$-ZIFs/PAN nanofibers by carbonization, oxidation, and sulfurization in different atmospheres (Ar, Air, and $\mathrm{H}_{2} \mathrm{~S}$ ) at $800{ }^{\circ} \mathrm{C}$ is shown in Figure 6. After carbonization, all the ratio of $\mathrm{Ni}$ and $\mathrm{Co}$ was close to the theoretical ratio before carbonization. During carbonization in only Ar atmosphere, the carbon element content remained at $42.14 \%$. After oxidation treatment in the Air, oxygen content increased as expected to $21.94 \%$, while carbon content decreased to $8.82 \%$, which may be due to the generation of carbon dioxide. After the sulfurization process, it was found that there were a lot of sulfur elements up to about $31.85 \%$. 


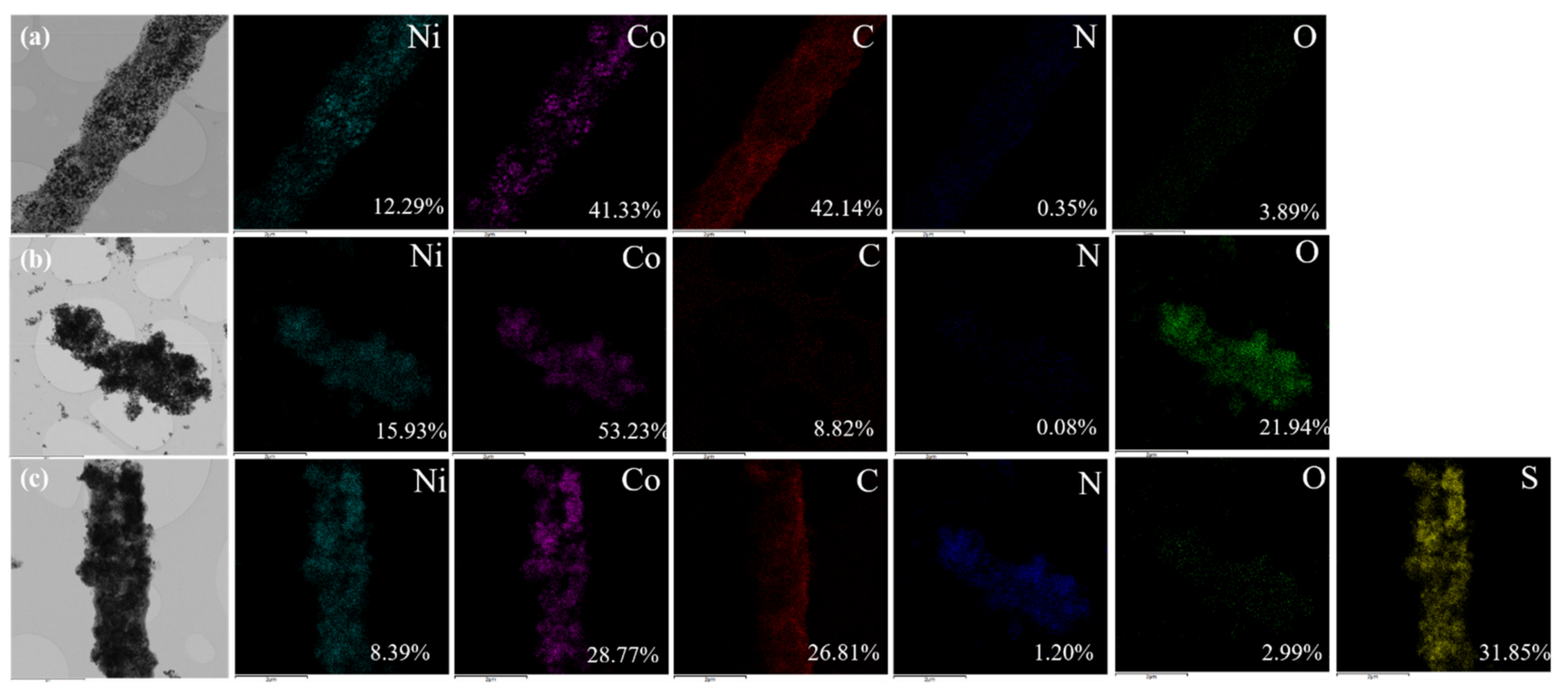

Figure 6. The TEM images and elemental mappings of multi-doped porous carbon nanofibers derived from $\mathrm{Ni}_{1} \mathrm{Co}_{4}$-ZIFs/PAN nanofibers by (a) carbonization, (b) oxidation, and (c) sulfurization in different atmospheres (Ar, Air, and $\mathrm{H}_{2} \mathrm{~S}$ ) at $800{ }^{\circ} \mathrm{C}$.

From Figure 7, the XRD characterization was done to study the crystal composition changes in different carbonization atmospheres. For $\mathrm{Ni}_{\mathrm{x}} \mathrm{Co}_{\mathrm{y}}-\mathrm{ZIFs} / \mathrm{PAN}-\mathrm{Ar}$, the XRD pattern showed the diffraction peaks of two main metallic elements at $44.5^{\circ}$ and $51.8^{\circ}$, which proved that $\mathrm{Ni}_{\mathrm{x}} \mathrm{Co}_{\mathrm{y}}$ alloy metal doping was realized [33]. Examining $\mathrm{Ni}_{\mathrm{x}} \mathrm{Co}_{\mathrm{y}}$ ZIFs/PAN-Air, the XRD pattern revealed diffraction peaks of multiple metal oxides at $36.8^{\circ}, 44.3^{\circ}, 59.8^{\circ}$, and $65.0^{\circ}$, indicating $\mathrm{Ni}_{\mathrm{x}} \mathrm{Co}_{\mathrm{y}}$ metal oxides doping was achieved $[34,35]$. Moreover, the XRD patterns of $\mathrm{Ni}_{x} \mathrm{Co}_{\mathrm{y}}-\mathrm{ZIFs} / \mathrm{PAN}-\mathrm{H}_{2} \mathrm{~S}$ offered $\mathrm{Ni}_{\mathrm{x}} \mathrm{Co}_{\mathrm{y}}$ metallic sulfide diffraction peaks at $30.8^{\circ}, 35.1^{\circ}, 47.2^{\circ}$, and $54.7^{\circ}$, which affirmed multiple metallic sulfide doping. Hence, the results above demonstrated that carbonization could be used to prepare catalyst materials with various doping types in different atmospheres $[29,36]$. The weak and broad peak observed around $26.2^{\circ}$ indicated that very little graphitic carbon was present $[37,38]$.

The $\mathrm{Ni}_{1} \mathrm{Co}_{4}$-ZIFs/PAN nanofiber was then selected for further characterizations under different atmospheres because of its higher crystallinity and structural stability according to XRD, SEM, and TEM-EDS earlier discussed. As depicted in Figure 8a-c, the XPS spectrum of the $\mathrm{Ni}_{1} \mathrm{Co}_{4}$-ZIFs/PAN material contains $\mathrm{Ni}, \mathrm{Co}, \mathrm{C}, \mathrm{N}, \mathrm{O}$, and $\mathrm{S}$ (under $\mathrm{H}_{2} \mathrm{~S}$ only) elements. The $\mathrm{S} 2 \mathrm{p}$ spectrum (Figure $8 \mathrm{~d}$ ), from the $\mathrm{H}_{2} \mathrm{~S}$ atmosphere, offered peaks at 170.4, 162.6, 165.2 , and $164.1 \mathrm{eV}$, which corresponded to SOx, thiophene $\mathrm{S}, 2 \mathrm{p}_{1 / 2}$, and $2 \mathrm{p}_{3 / 2}$ in CoS, respectively [31,39]. For $\mathrm{C} 1 \mathrm{~s}$ (Figure $8 \mathrm{e}, \mathrm{i}, \mathrm{m}$ ), the peaks at 284.8, 285.5, and $288.1 \mathrm{eV}$ were identified as $\mathrm{C}=\mathrm{C}$, saturated carbon $(\mathrm{C}-\mathrm{S}, \mathrm{C}-\mathrm{O}, \mathrm{C}-\mathrm{N})$, and unsaturated carbon species $(\mathrm{C}=\mathrm{O}, \mathrm{C}=\mathrm{N})$ respectively $[31,40]$. The N1s spectrum (Figure $8 \mathrm{f}, \mathrm{j}, \mathrm{n})$ was represented by four components at 403.2, 401.5, 399.6, and $398.5 \mathrm{eV}$, denoting oxidized $\mathrm{N}$, graphitic $\mathrm{N}$, pyrrolic $\mathrm{N}$, and pyridinic $\mathrm{N}[31,41]$. 

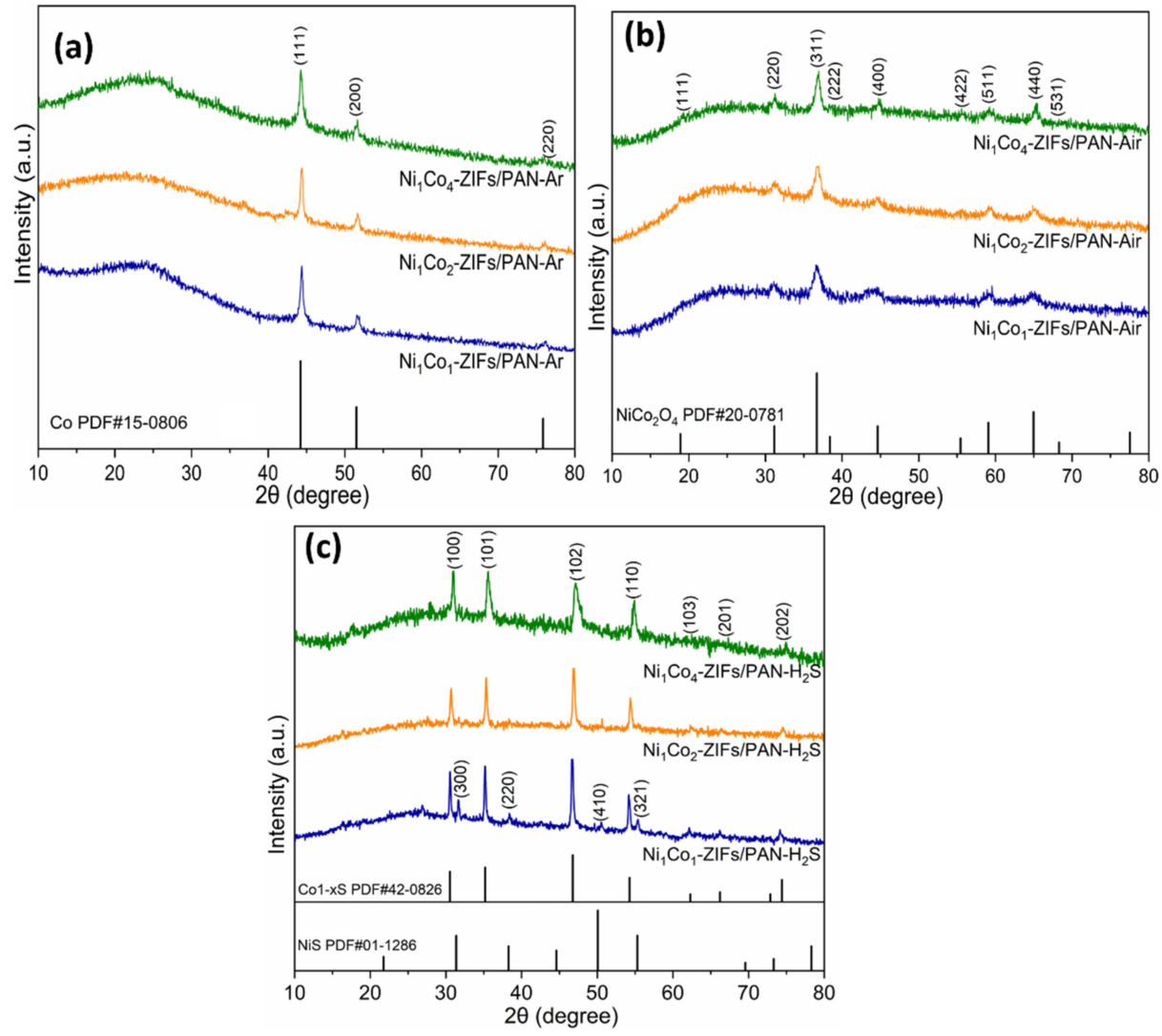

Figure 7. The XRD patterns of multi-doped porous carbon nanofibers derived from different $\mathrm{Ni}_{\mathrm{x}} \mathrm{Co}_{\mathrm{y}}-$ ZIFs/PAN nanofibers by (a) carbonization, (b) oxidation, and (c) sulfurization in different atmospheres (Ar, Air, and $\mathrm{H}_{2} \mathrm{~S}$ ) at $800{ }^{\circ} \mathrm{C}$.

Moreover, the Co $2 \mathrm{p}$ spectrum had $2 \mathrm{p}_{1 / 2}$ and $2 \mathrm{p}_{3 / 2}$ components, as shown in Figure $8 \mathrm{~g}$. Under $\mathrm{H}_{2} \mathrm{~S}$ exposure, the obtained peaks at 799.5 and $783.7 \mathrm{eV}$ were related to the $\mathrm{Co}^{2+}$ species [42], whereas those at 778.7 and $797.8 \mathrm{eV}$ were for $\mathrm{Co}^{3+}$, respectively [43,44]. In Air (Figure $8 \mathrm{k}$ ), the peaks at 795.3 and $780.4 \mathrm{eV}$ were attributed to $\mathrm{Co}^{3+}$, while those at 782 and $796.8 \mathrm{eV}$ were for $\mathrm{Co}^{2+}$, respectively [45]. The satellite components appeared at 802.9 and $786.7 \mathrm{eV}$ [46]. Under $\mathrm{Ar}$ (Figure 80), the peaks at 796.9 and $781.6 \mathrm{eV}$ were characterized as $\mathrm{Co}^{2+}$, while those at 794.5 and $779 \mathrm{eV}$ were assigned to $\mathrm{Co}^{3+}$ species $[43,45]$.

Considering Ni $2 \mathrm{p}$ under $\mathrm{H}_{2} \mathrm{~S}$ atmosphere (Figure $8 \mathrm{~h}$ ), the Ni2 $\mathrm{p}_{1 / 2}$ and $\mathrm{Ni} 2 \mathrm{p}_{3 / 2}$ peaks were observed at 874.7 and $856 \mathrm{eV}$, respectively [47]. From Figure $81, \mathrm{Ni} 2 \mathrm{p}_{1 / 2}$ and Ni2 $\mathrm{p}_{3 / 2}$ peaks were identified at 872.6 and $856 \mathrm{eV}$, besides the two shake-up satellites. Under $\mathrm{Ar}$ (Figure 8p), these main peaks occurred at 872.3 and $855.4 \mathrm{eV}$, respectively [48,49]. The increased binding energies witnessed in Co $2 p$ and Ni $2 p$ for the $\mathrm{H}_{2} \mathrm{~S}$ atmosphere can be ascribed to higher oxidation characteristics occurring after S-doping [50]. 


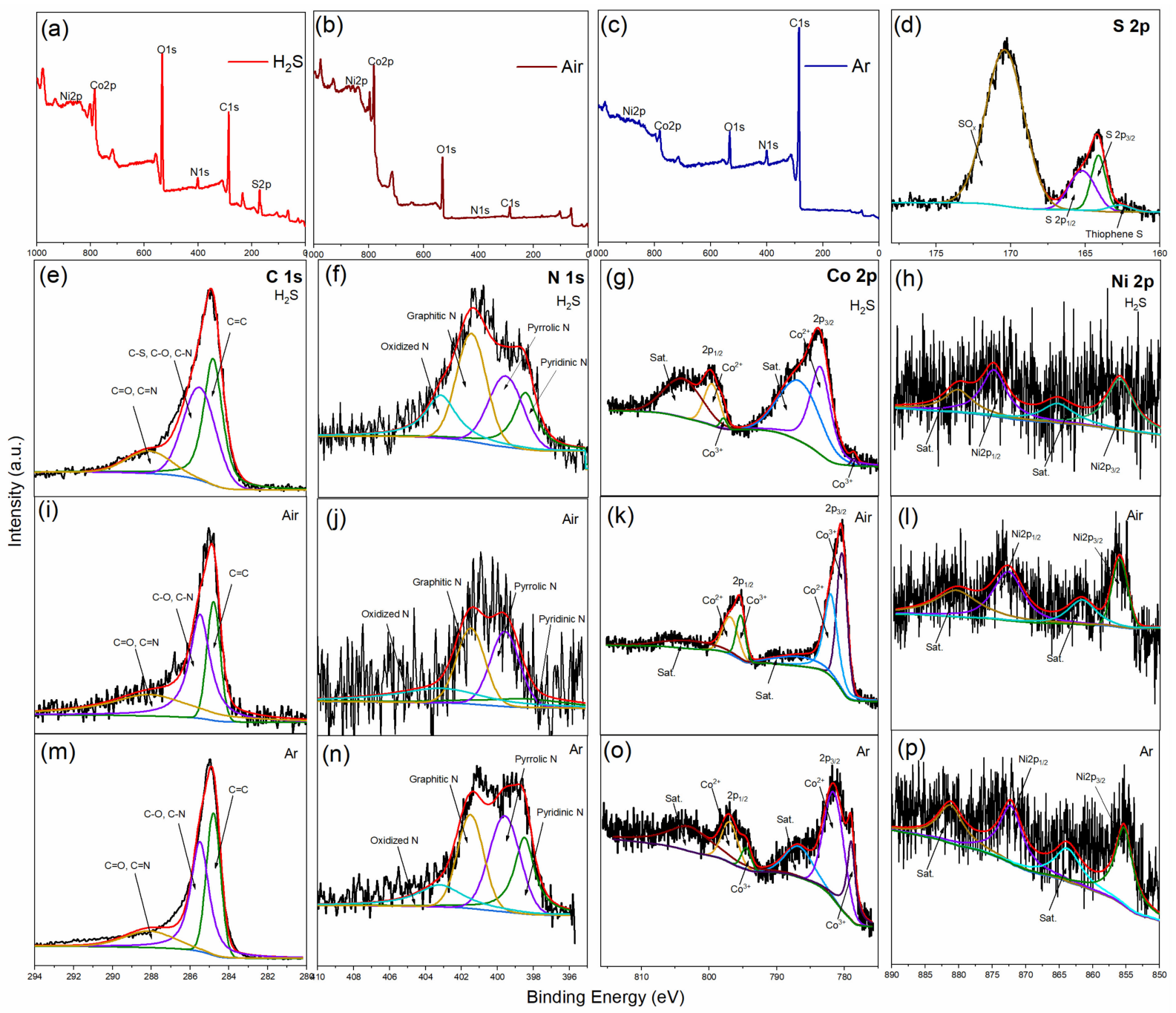

Figure 8. X-ray photoelectron spectrum of $\mathrm{Ni}_{1} \mathrm{Co}_{4}$-ZIFs/PAN nanofiber under different atmospheres (Ar, Air, and $\left.\mathrm{H}_{2} \mathrm{~S}\right)$; Survey spectrum (a-c), S 2p (d), C 1s (e,i,m), N 1s (f,j, $\left.\mathbf{j}\right)$, Co $2 \mathrm{p}(\mathbf{g}, \mathbf{k}, \mathbf{o})$, and Ni 2p $(h, l, p)$.

The effects of different carbonization processes on specific surface area and porosity were examined using nitrogen sorption curves of the materials (Figure 9). The catalyst specific surface areas gained by carbonization in $\mathrm{Ar}$, Air, and $\mathrm{H}_{2} \mathrm{~S}$ atmosphere were 484.27, 489.37, and $461.70 \mathrm{~m}^{2} \mathrm{~g}^{-1}$, respectively. The pore size distribution was primarily centered at about $5 \mathrm{~nm}$. After Air oxidation, it was found that the hysteresis region of nitrogen adsorption and desorption curve had no apparent change. The distribution was primarily concentrated below $10 \mathrm{~nm}$. It was noted that the hysteresis of nitrogen adsorption and desorption curve decreased after sulfurization, whereas the distribution of the pore sizes increased to 15-20 $\mathrm{nm}$. The pore structure and specific surface area tend to affect the catalytic performance of catalysts. 

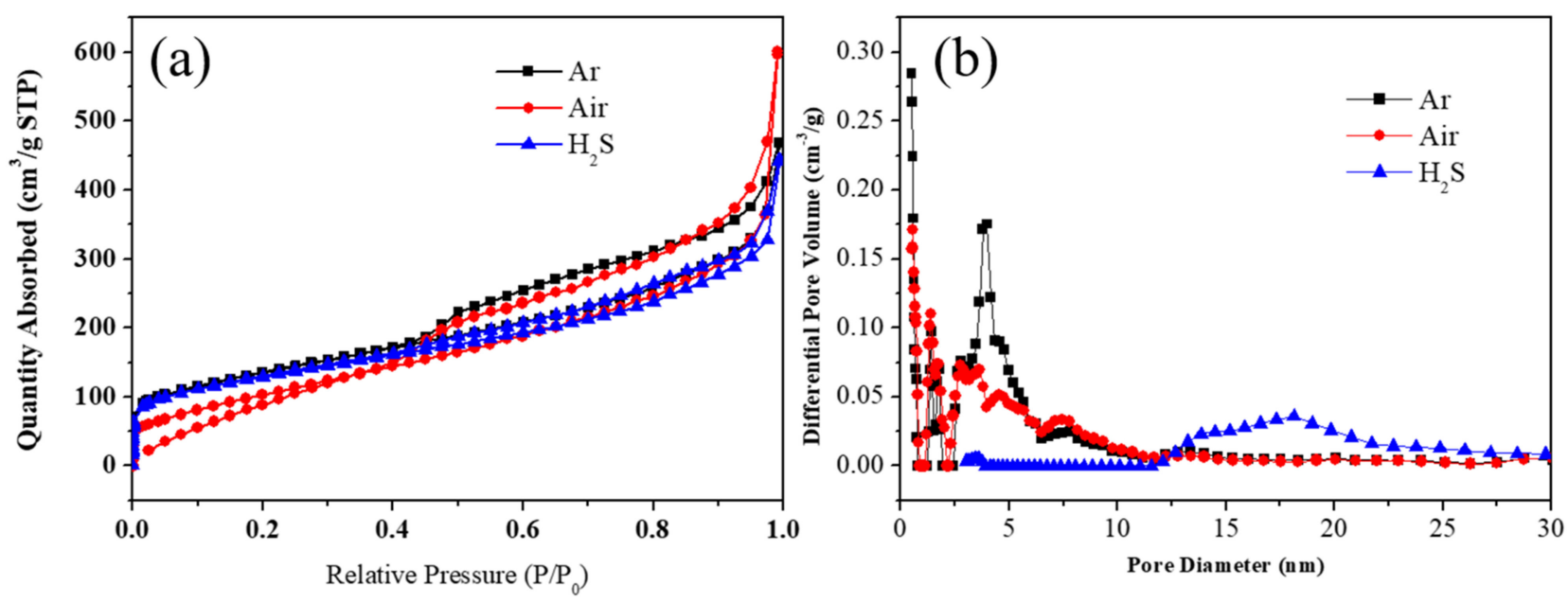

Figure 9. The (a) $\mathrm{N}_{2}$ sorption isotherm plots and (b) pore size distribution curves of multi-doped porous carbon nanofibers derived from different $\mathrm{Ni}_{1} \mathrm{Co}_{4}$-ZIFs/PAN nanofibers by carbonization, oxidation, and sulfurization in different atmospheres (Ar, Air, and $\mathrm{H}_{2} \mathrm{~S}$ ) at $800{ }^{\circ} \mathrm{C}$.

The ORR and OER performances under different carbonization states were studied. As depicted in Figure 10a, the $\mathrm{Ni}_{1} \mathrm{Co}_{2}$-ZIFs/PAN-Ar sample had the best ORR output. The overall improvement in the Ar-carbonized sample towards ORR could be attributed to its higher pyridinic $\mathrm{N}$ amount compared to those in Air and $\mathrm{H}_{2} \mathrm{~S}$. This could boost ORR performance via a 4-electron pathway [51,52]. Moreover, the larger mesoporous arrangement in the Ar-carbonized samples increased the active sites for mass transfer, thereby inducing better electrochemical properties $[53,54]$. In terms of OER behavior in $\mathrm{Ni}_{\mathrm{x}} \mathrm{Co}_{\mathrm{y}}$ ZIFs/PAN-Ar samples (Figure 10b), there were no significant changes in potential value at $10 \mathrm{~mA} \cdot \mathrm{cm}^{-2}$. Figure 10c showed that the ORR of $\mathrm{Ni}_{x} \mathrm{Co}_{\mathrm{y}}$-ZIFs/PAN-Air decreased after the oxidation process. However, their OER performances were significantly enhanced, especially for $\mathrm{Ni}_{1} \mathrm{Co}_{1}$-ZIFs/PAN-Air (Figure 10d). After the sulfurization process (Figure 9e), the ORR yields were better than oxidation but worse than carbonation products in the Ar atmosphere. After sulfurization, the OER performance of $\mathrm{Ni}_{1} \mathrm{Co}_{4}-\mathrm{ZIFs} / \mathrm{PAN}-\mathrm{H}_{2} \mathrm{~S}$ was better than the other samples (Figure 10f). In addition, it was observed from Figure 10a,c,e that when the ratio of $\mathrm{Ni} / \mathrm{Co}$ was $1 / 2$, their ORR catalytic performance was better than the other ratios. Meanwhile, as illustrated in Figure 10b,f, when the ratio of Ni/Co was 1/4, their OER catalytic performances were better compared to the other ratios. 

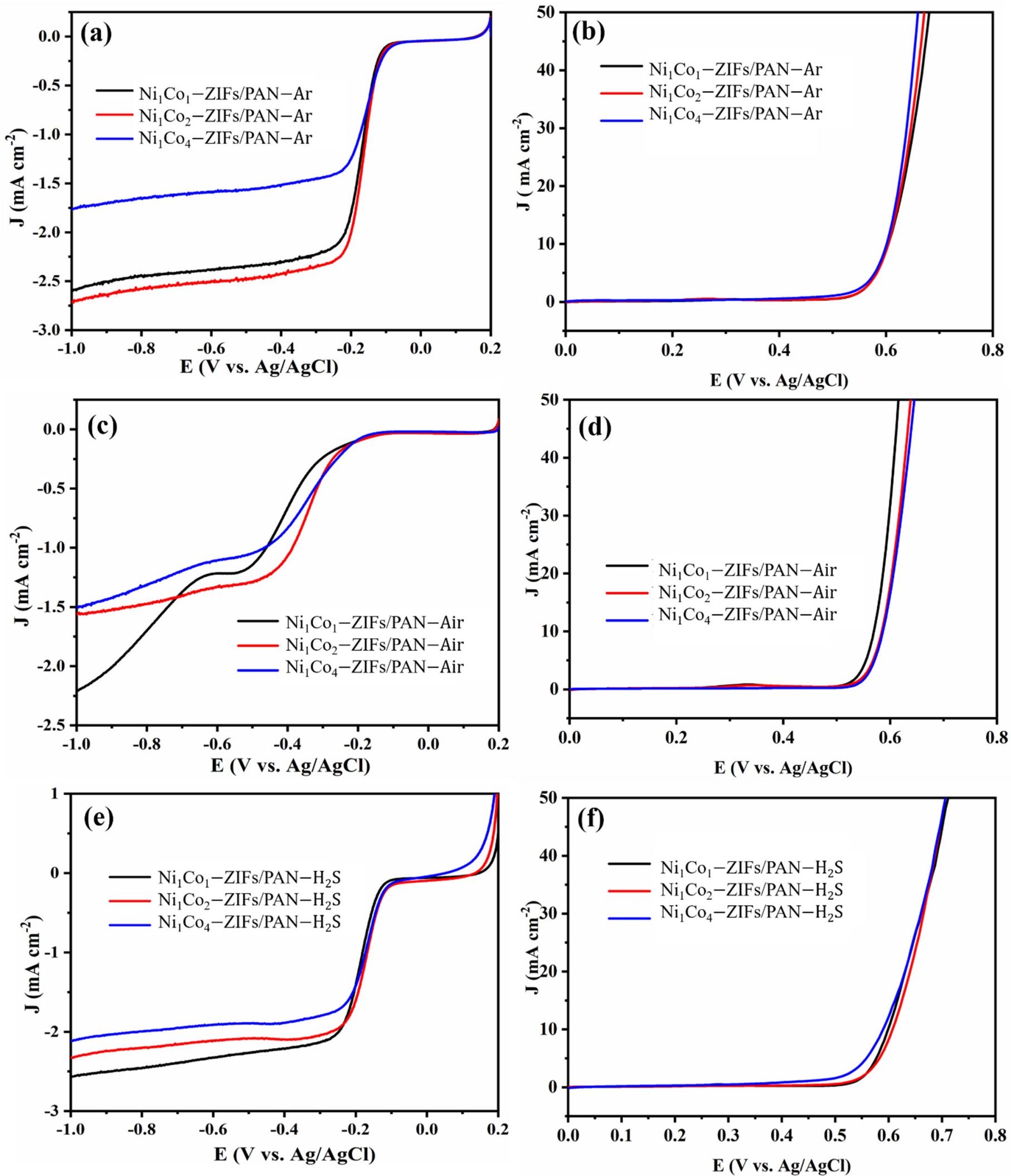

Figure 10. The ORR and OER performances of multi-doped porous carbon nanofibers derived from different $\mathrm{Ni}_{\mathrm{x}} \mathrm{Co}_{\mathrm{y}}$-ZIFs/PAN nanofibers by $(\mathbf{a}, \mathbf{b})$ carbonization, $(\mathbf{c}, \mathbf{d})$ oxidation, and $(\mathbf{e}, \mathbf{f})$ sulfurization in different atmospheres (Ar, Air, and $\left.\mathrm{H}_{2} \mathrm{~S}\right)$ at $800^{\circ} \mathrm{C}$. 
Moreover, the catalyst stability for $\mathrm{Ni}_{1} \mathrm{Co}_{2}$-ZIFs / PAN-Ar and $\mathrm{Ni}_{1} \mathrm{Co}_{1}-\mathrm{ZIFs} / \mathrm{PAN}-\mathrm{Air}$ were examined. The chronoamperometric measurement for 18,000 s (Figures S1 and S2) offered current retention values of $62.96 \%$ (ORR) and $33.80 \%$ (OER) for $\mathrm{Ni}_{1} \mathrm{Co}_{2}$-ZIFs $/ \mathrm{PAN}-$ $\mathrm{Ar}$ and $\mathrm{Ni}_{1} \mathrm{Co}_{1}-\mathrm{ZIFs} / \mathrm{PAN}-\mathrm{Air}$, respectively. Moreover, after using the best ORR catalyst, $\mathrm{Ni}_{1} \mathrm{Co}_{2}$-ZIFs/PAN, as oxygen cathodes in rechargeable $\mathrm{Zn}$-Air batteries under the three atmospheres, Ar gave a higher peak power density of $41.96 \mathrm{~mW} \cdot \mathrm{cm}^{-2}$ (Figure S3).

The electrochemical impedance spectroscopy (EIS) was conducted for all the samples (Figure S4). This was carried out in $5 \mathrm{mM}\left[\mathrm{Fe}(\mathrm{CN})_{6}\right]^{3-/ 4-}$ with $0.1 \mathrm{M} \mathrm{KCl}$ solutions at a bias potential of $0.23 \mathrm{~V}$. The amplitude was set at $10 \mathrm{mV}$ and the frequency ranged from 0.1 to $100 \mathrm{~Hz}$. Similar outputs were observed in $\mathrm{Ni}_{1} \mathrm{Co}_{2}-\mathrm{ZIFs} / \mathrm{PAN}$ and $\mathrm{Ni}_{1} \mathrm{Co}_{4}$ ZIFs/PAN materials under Air and $\mathrm{H}_{2} \mathrm{~S}$ atmospheres. The most shifted Nyquist plot semi-circles witnessed for the atmospheres followed the order; $\mathrm{Ni}_{1} \mathrm{Co}_{1}$-ZIFs /PAN-Air > $\mathrm{Ni}_{1} \mathrm{Co}_{4}$-ZIFs/PAN-Ar $>\mathrm{Ni}_{1} \mathrm{Co}_{1}$-ZIFs $/ \mathrm{PAN}-\mathrm{H}_{2} \mathrm{~S}$. Moreover, the Koutecky-Levich (K-L) plot, deduced from polarization curves at different rotation rates (Figures S5-S7), $\mathrm{Ni}_{\mathrm{x}} \mathrm{Co}_{\mathrm{y}}-$ ZIFs/PAN-Ar samples showed good linearity and this approximately implied first-orderreaction kinetics [55].

\section{Conclusions}

In summary, bimetallic $\mathrm{Ni}_{\mathrm{x}} \mathrm{Co}_{\mathrm{y}}$-ZIFs were prepared by hydrothermal synthesis. The best crystalline structure was achieved when the $\mathrm{Ni} / \mathrm{Co}$ ratio was $1 / 4$. One-dimensional $\mathrm{Ni}_{\mathrm{x}} \mathrm{Co}_{\mathrm{y}}$-ZIFs/PAN nanofiber precursors were synthesized by simple electrospinning. Subsequently, $\mathrm{Ni}_{\mathrm{x}} \mathrm{Co}_{\mathrm{y}}$ bimetallic compound doped porous carbon nanofiber catalysts with $\mathrm{N}, \mathrm{O}$, $\mathrm{S}$ doping were obtained by carbonization under different gas $\left(\mathrm{Ar}, \mathrm{Air}, \mathrm{H}_{2} \mathrm{~S}\right)$ atmospheres, respectively. The morphology, structure, crystal composition, elemental content, and specific surface area of the carbonized catalysts were characterized by SEM, TEM, XRD, elemental mapping, and BET. The carbon content of the nanofiber decreased, and the nanoparticles agglomerated during the oxidation process, leading to nanofiber fracture. The S-doping reduced the specific surface area and increased the nanofiber pore size. Importantly, it was found that $\mathrm{Ni}_{1} \mathrm{Co}_{2}$-ZIFs/PAN-Ar and $\mathrm{Ni}_{1} \mathrm{Co}_{1}$-ZIFs/PAN-Air yielded the best results for ORR $(-0.09 \mathrm{~V}$ vs. $\mathrm{Ag} / \mathrm{AgCl})$ and $\mathrm{OER}(0.57 \mathrm{~V}$ vs. $\mathrm{Ag} / \mathrm{AgCl})$ performances after the carbonization process, respectively. In addition, $\mathrm{Ni}_{1} \mathrm{Co}_{4}$-ZIFs / PAN-Ar offered better peak power density of $41.96 \mathrm{~mW} \cdot \mathrm{cm}^{-2}$.

Supplementary Materials: The following supporting information can be downloaded at: https: / / www.mdpi.com/article/10.3390/nano12050832/s1, Figure S1: Electrocatalytic stability of $\mathrm{Ni}_{1} \mathrm{Co}_{2}$ ZIFs/PAN-Ar in $\mathrm{O}_{2}$-saturated $0.1 \mathrm{M} \mathrm{KOH}$ aqueous solution at ${ }^{\mathrm{TM}} 0.30 \mathrm{~V}$ (vs. $\mathrm{Ag} / \mathrm{AgCl}$ ); Figure S2: Electrocatalytic stability of $\mathrm{Ni}_{1} \mathrm{Co}_{1}$-ZIFs/PAN-Air in $\mathrm{O}_{2}$-saturated $1.0 \mathrm{M} \mathrm{KOH}$ aqueous solution at $0.60 \mathrm{~V}$ (vs. $\mathrm{Ag} / \mathrm{AgCl}$ ); Figure S3: Discharge polarization and power density curves of $\mathrm{Zn}$-air batteries using $\mathrm{Ni}_{1} \mathrm{Co}_{2}-\mathrm{ZIFs} / \mathrm{PAN}$ under (a) $\mathrm{Ar}$ (b) Air and (c) $\mathrm{H}_{2} \mathrm{~S}$ as ORR catalysts (mass loading of $1.2 \mathrm{mg} \mathrm{cm}^{-2}$ ); Figure S4: EIS patterns of $\mathrm{Ni}_{\mathrm{x}} \mathrm{Co}_{\mathrm{y}}$-ZIFs/PAN nanofibers under different atmospheres (Ar, Air, and $\mathrm{H}_{2} \mathrm{~S}$ ) at $0.23 \mathrm{~V}$; Figure S5: LSV curves of $\mathrm{Ni}_{x} \mathrm{Co}_{\mathrm{y}}$-ZIFs/PAN nanofibers at different rotation speeds from 400 to $2025 \mathrm{rpm}(\mathrm{a}, \mathrm{c}, \mathrm{e}), \mathrm{K}-\mathrm{L}$ plots of $\mathrm{Ni}_{\mathrm{x}} \mathrm{Co}_{\mathrm{y}}-\mathrm{ZIFs} / \mathrm{PAN}$ nanofibers under Ar atmosphere at different potentials $(\mathrm{b}, \mathrm{d}, \mathrm{f})$; Figure S6: LSV curves of $\mathrm{Ni}_{\mathrm{x}} \mathrm{Co}_{\mathrm{y}}-\mathrm{ZIFs} / \mathrm{PAN}$ nanofibers at different rotation speeds from 400 to $2025 \mathrm{rpm}(\mathrm{a}, \mathrm{c}, \mathrm{e}), \mathrm{K}-\mathrm{L}$ plots of $\mathrm{Ni}_{\mathrm{x}} \mathrm{Co}_{\mathrm{y}}$-ZIFs/PAN nanofibers under Air atmosphere at different potentials $(\mathrm{b}, \mathrm{d}, \mathrm{f})$; Figure S7: LSV curves of $\mathrm{Ni}_{\mathrm{x}} \mathrm{Co}_{\mathrm{y}}-\mathrm{ZIFs} / \mathrm{PAN}$ nanofibers at different rotation speeds from 400 to $2025 \mathrm{rpm}(\mathrm{a}, \mathrm{c}, \mathrm{e}), \mathrm{K}-\mathrm{L}$ plots of $\mathrm{Ni}_{\mathrm{x}} \mathrm{Co}_{\mathrm{y}}$-ZIFs/PAN nanofibers under $\mathrm{H}_{2} \mathrm{~S}$ atmosphere at different potentials $(\mathrm{b}, \mathrm{d}, \mathrm{f})$.

Author Contributions: Conceptualization, N.W. and. Y.Z.; experiment, Q.N.; writing-original draft preparation, T.W., O.O. and Y.L.; writing - review and editing Q.N., M.F.D. and L.C.; project administration, Q.N.; funding acquisition, Q.N. and L.C. All authors have read and agreed to the published version of the manuscript.

Funding: This research was funded by China Postdoctoral Science Foundation (Grant no. 2020M671359); Natural Science Foundation of Jiangsu Province (Grant no. BK20200914); National Natural Science Foundation of China (Grant no. 62101216); Priority Academic Program Development of Jiangsu Higher 
Education Institutions (Grant no. PAPD-2018-87) and Jiangsu Distinguished professor and Jiangsu Province Key project of Research and Development Plan (Grant no. BE2020676).

Institutional Review Board Statement: Not applicable.

Informed Consent Statement: Not applicable.

Data Availability Statement: The data presented in this study are available on request from the corresponding author.

Conflicts of Interest: The authors declare no conflict of interest.

\section{References}

1. Wu, G.; Santandreu, A.; Kellogg, W.; Gupta, S.; Ogoke, O.; Zhang, H.; Wang, H.-L.; Dai, L. Carbon nanocomposite catalysts for oxygen reduction and evolution reactions: From nitrogen doping to transition-metal addition. Nano Energy 2016, 29, 83-110. [CrossRef]

2. Ruan, M.; Liu, J.; Song, P.; Xu, W. Meta-analysis of commercial Pt/C measurements for oxygen reduction reactions via data mining. Chin. J. Catal. 2022, 43, 116-121. [CrossRef]

3. Gonzalez-Huerta, R.G.; Ramos-Sanchez, G.; Balbuena, P.B. Oxygen evolution in Co-doped $\mathrm{RuO}_{2}$ and $\mathrm{IrO}_{2}$ : Experimental and theoretical insights to diminish electrolysis overpotential. J. Power Sources 2014, 268, 69-76. [CrossRef]

4. $\quad \mathrm{Wu}$, X.; Niu, Y.; Feng, B.; Yu, Y.; Huang, X.; Zhong, C.; Hu, W.; Li, C.M. Mesoporous Hollow Nitrogen-Doped Carbon Nanospheres with Embedded MnFe2O4/Fe Hybrid Nanoparticles as Efficient Bifunctional Oxygen Electrocatalysts in Alkaline Media. ACS Appl. Mater. Interfaces 2018, 10, 20440-20447. [CrossRef]

5. Ma, L.-L.; Hu, X.; Liu, W.-J.; Li, H.-C.; Lam, P.K.S.; Zeng, R.J.; Yu, H.-Q. Constructing N, P-dually doped biochar materials from biomass wastes for high-performance bifunctional oxygen electrocatalysts. Chemosphere 2021, 278, 130508. [CrossRef]

6. Sun, J.; Lowe, S.E.; Zhang, L.; Wang, Y.; Pang, K.; Wang, Y.; Zhong, Y.; Liu, P.; Zhao, K.; Tang, Z. Ultrathin nitrogen-doped holey carbon@ graphene bifunctional electrocatalyst for oxygen reduction and evolution reactions in alkaline and acidic media. Angew. Chem. Int. Ed. 2018, 57, 16511-16515. [CrossRef]

7. Morales, D.M.; Kazakova, M.A.; Dieckhöfer, S.; Selyutin, A.G.; Golubtsov, G.V.; Schuhmann, W.; Masa, J. Trimetallic Mn-Fe-Ni oxide nanoparticles supported on multi-walled carbon nanotubes as high-performance bifunctional ORR/OER electrocatalyst in alkaline media. Adv. Funct. Mater. 2020, 30, 1905992. [CrossRef]

8. Zhang, W.; Yao, X.; Zhou, S.; Li, X.; Li, L.; Yu, Z.; Gu, L. ZIF-8/ZIF-67-derived Co-Nx-embedded 1D porous carbon nanofibers with graphitic carbon-encased Co nanoparticles as an efficient bifunctional electrocatalyst. Small 2018, 14, 1800423. [CrossRef]

9. Meng, Y.; Huang, X.; Lin, H.; Zhang, P.; Gao, Q.; Li, W. Carbon-based nanomaterials as sustainable noble-metal-free electrocatalysts. Front. Chem. 2019, 7, 759. [CrossRef]

10. Osgood, H.; Devaguptapu, S.V.; Xu, H.; Cho, J.; Wu, G. Transition metal (Fe, Co, Ni, and Mn) oxides for oxygen reduction and evolution bifunctional catalysts in alkaline media. Nano Today 2016, 11, 601-625. [CrossRef]

11. Hu, C.; Paul, R.; Dai, Q.; Dai, L. Carbon-based metal-free electrocatalysts: From oxygen reduction to multifunctional electrocatalysis. Chem. Soc. Rev. 2021, 50, 11785-11843. [CrossRef] [PubMed]

12. Chen, Z.; Zhao, B.; He, Y.-C.; Wen, H.-R.; Fu, X.-Z.; Sun, R.; Wong, C.-P. NiCo $\mathrm{O}_{4}$ nanoframes with a nanosheet surface as efficient electrocatalysts for the oxygen evolution reaction. Mater. Chem. Front. 2018, 2, 1155-1164. [CrossRef]

13. Faraji, M.; Arianpouya, N. NiCoFe-layered double hydroxides/MXene/N-doped carbon nanotube composite as a high performance bifunctional catalyst for oxygen electrocatalytic reactions in metal-air batteries. J. Electroanal. Chem. 2021, $901,115797$. [CrossRef]

14. Lian, Y.; Shi, K.; Yang, H.; Sun, H.; Qi, P.; Ye, J.; Wu, W.; Deng, Z.; Peng, Y. Elucidation of Active Sites on S, N Codoped Carbon Cubes Embedding Co-Fe Carbides toward Reversible Oxygen Conversion in High-Performance Zinc-Air Batteries. Small 2020, 16, 1907368. [CrossRef] [PubMed]

15. Yan, S.; Luo, C.; Zhang, H.; Yang, L.; Huang, N.; Zhang, M.; Yu, H.; Sun, P.; Wang, L.; Lv, X.; et al. In-Situ derived Co $1-x$ S@nitrogendoped carbon nanoneedle array as a bifunctional electrocatalyst for flexible Zinc-air battery. J. Electroanal. Chem. 2021, 900, 115711. [CrossRef]

16. Vijayakumar, E.; Ramakrishnan, S.; Sathiskumar, C.; Yoo, D.J.; Balamurugan, J.; Noh, H.S.; Kwon, D.; Kim, Y.H.; Lee, H. MOFderived CoP-nitrogen-doped carbon@NiFeP nanoflakes as an efficient and durable electrocatalyst with multiple catalytically active sites for OER, HER, ORR and rechargeable zinc-air batteries. Chem. Eng. J. 2022, 428, 131115. [CrossRef]

17. Kim, H.; Prasad Tiwari, A.; Mukhiya, T.; Kim, H.Y. Temperature-controlled in situ synthesized carbon nanotube-protected vanadium phosphate particle-anchored electrospun carbon nanofibers for high energy density symmetric supercapacitors. $J$. Colloid Interface Sci. 2021, 600, 740-751. [CrossRef]

18. Li, Y.; Zhu, J.; Cheng, H.; Li, G.; Cho, H.; Jiang, M.; Gao, Q.; Zhang, X. Developments of Advanced Electrospinning Techniques: A Critical Review. Adv. Mater. Technol. 2021, 6, 2100410. [CrossRef]

19. Lei, Y.; Wang, Q.; Peng, S.; Ramakrishna, S.; Zhang, D.; Zhou, K. Electrospun Inorganic Nanofibers for Oxygen Electrocatalysis: Design, Fabrication, and Progress. Adv. Energy Mater. 2020, 10, 1902115. [CrossRef] 
20. Dapaah, M.F.; Niu, Q.; Yu, Y.-Y.; You, T.; Liu, B.; Cheng, L. Efficient persistent organic pollutant removal in water using MIL-metal-organic framework driven Fenton-like reactions: A critical review. Chem. Eng. J. 2022, 431, 134182. [CrossRef]

21. Liu, B.; Wong-Foy, A.G.; Matzger, A.J. Rapid and enhanced activation of microporous coordination polymers by flowing supercritical $\mathrm{CO}_{2}$. Chem. Commun. 2013, 49, 1419-1421. [CrossRef]

22. Dapaah, M.F.; Liu, B. Recent advances of supercritical $\mathrm{CO}_{2}$ in green synthesis and activation of metal-organic frameworks. J. Inorg. Organomet. Polym. Mater. 2020, 30, 581-595. [CrossRef]

23. Dapaah, M.F.; Liu, B.; Cheng, L. Adsorption of organic compounds from aqueous solution by pyridine-2-carboxaldehyde grafted MIL-101(Cr)- $\mathrm{NH}_{2}$ metal-organic frameworks. J. Environ. Chem. Eng. 2021, 9, 105275. [CrossRef]

24. Wang, H.-F.; Chen, L.; Pang, H.; Kaskel, S.; Xu, Q. MOF-derived electrocatalysts for oxygen reduction, oxygen evolution and hydrogen evolution reactions. Chem. Soc. Rev. 2020, 49, 1414-1448. [CrossRef]

25. Muthurasu, A.; Tiwari, A.P.; Chhetri, K.; Dahal, B.; Kim, H.Y. Construction of iron doped cobalt- vanadate- cobalt oxide with metal-organic framework oriented nanoflakes for portable rechargeable zinc-air batteries powered total water splitting. Nano Energy 2021, 88, 106238. [CrossRef]

26. Li, Y.-W.; Zhang, W.-J.; Li, J.; Ma, H.-Y.; Du, H.-M.; Li, D.-C.; Wang, S.-N.; Zhao, J.-S.; Dou, J.-M.; Xu, L. Fe-MOF-Derived Efficient ORR/OER Bifunctional Electrocatalyst for Rechargeable Zinc-Air Batteries. ACS Appl. Mater. Interfaces 2020, 12, 44710-44719. [CrossRef]

27. Pan, Y.; Abazari, R.; Wu, Y.; Gao, J.; Zhang, Q. Advances in metal-organic frameworks and their derivatives for diverse electrocatalytic applications. Electrochem. Commun. 2021, 126, 107024. [CrossRef]

28. Li, H.; Wu, G.; Cheng, G.; Shuai, Y.; Liu, S.; Liu, Y. CoNi nanoalloys embedded in N-doped carbon nanofibers derived from layered bimetal-organic framework and as efficient oxygen electrocatalyst. J. Alloys Compd. 2021, 888, 161588. [CrossRef]

29. Chen, B.; Ma, G.; Zhu, Y.; Wang, J.; Xiong, W.; Xia, Y. Metal-organic-framework-derived bi-metallic sulfide on N, S-codoped porous carbon nanocomposites as multifunctional electrocatalysts. J. Power Sources 2016, 334, 112-119. [CrossRef]

30. Niu, Q.; Chen, B.; Guo, J.; Nie, J.; Guo, X.; Ma, G. Flexible, Porous, and Metal-Heteroatom-Doped Carbon Nanofibers as Efficient ORR Electrocatalysts for Zn-Air Battery. Nano-Micro Lett. 2019, 11, 8. [CrossRef]

31. Niu, Q.; Ola, O.; Chen, B.; Zhu, Y.; Xia, Y.; Ma, G. Metal Sulfide Nanoparticles Anchored N, S Co-doped Porous Carbon Nanofibers as Highly Efficient Bifunctional Electrocatalysts for Oxygen Reduction/Evolution Reactions. Int. J. Electrochem. Sci. 2020, 15, 4869-4883. [CrossRef]

32. Niu, Q.; Ola, O.; Wang, N.; Chen, B.; Zhu, Y.; Xia, Y. Carbon encapsulated $\mathrm{WS}_{2}$ nanocomposites derived from ZIF-67@WS 2 Core-Shell Nanoparticles and their electrocatalytic applications. Int. J. Electrochem. Sci. 2020, 15, 12370-12379. [CrossRef]

33. Peng, W.; Jin, J.; Yang, S.; Shen, Z.; Wang, H.; Zhang, J.; Li, G. NiCo Alloy Nanoparticles Anchored on Carbon Nanotube-Decorated Carbon Nanorods as a Durable and Efficient Oxygen Electrocatalyst for Zinc-Air Flow Batteries. ACS Appl. Energy Mater. 2021, 4 , 11041-11050. [CrossRef]

34. Liu, C.; Zuo, P.; Jin, Y.; Zong, X.; Li, D.; Xiong, Y. Defect-enriched carbon nanofibers encapsulating NiCo oxide for efficient oxygen electrocatalysis and rechargeable Zn-air batteries. J. Power Sources 2020, 473, 228604. [CrossRef]

35. Belkessam, C.; Bencherif, S.; Mechouet, M.; Idiri, N.; Ghilane, J. The Effect of Heteroatom Doping on Nickel Cobalt Oxide Electrocatalysts for Oxygen Evolution and Reduction Reactions. ChemPlusChem 2020, 85, 1710-1718. [CrossRef] [PubMed]

36. Chen, B.; Li, R.; Ma, G.; Gou, X.; Zhu, Y.; Xia, Y. Cobalt sulfide/N,S codoped porous carbon core-shell nanocomposites as superior bifunctional electrocatalysts for oxygen reduction and evolution reactions. Nanoscale 2015, 7, 20674-20684. [CrossRef]

37. Zhao, L.; Yang, A.; Wang, A.; Yu, H.; Dai, J.; Zheng, Y. ZIF-67 derived Co, Fe, Ni co-doped porous carbon as an efficient electrocatalyst for hydrogen evolution reaction. J. Porous Mater. 2020, 27, 1685-1690. [CrossRef]

38. Qiu, T.; Yang, J.-G.; Bai, X.-J.; Wang, Y.-L. The preparation of synthetic graphite materials with hierarchical pores from lignite by one-step impregnation and their characterization as dye absorbents. RSC Adv. 2019, 9, 12737-12746. [CrossRef]

39. Wang, S.; Gao, F.; Zhao, Y.; Liu, N.; Tan, T.; Wang, X. Two-dimensional $\mathrm{CeO}_{2} / \mathrm{RGO}$ composite-modified separator for lithium/sulfur batteries. Nanoscale Res. Lett. 2018, 13, 377. [CrossRef]

40. Tang, Y.-J.; Liu, C.-H.; Huang, W.; Wang, X.-L.; Dong, L.-Z.; Li, S.-L.; Lan, Y.-Q. Bimetallic Carbides-Based Nanocomposite as Superior Electrocatalyst for Oxygen Evolution Reaction. ACS Appl. Mater. Interfaces 2017, 9, 16977-16985. [CrossRef]

41. Hu, Z.; Guo, Z.; Zhang, Z.; Dou, M.; Wang, F. Bimetal zeolitic imidazolite framework-derived iron-, cobalt-and nitrogen-codoped carbon nanopolyhedra electrocatalyst for efficient oxygen reduction. ACS Appl. Mater. Interfaces 2018, 10, 12651-12658. [CrossRef] [PubMed]

42. Yang, M.; Sun, J.; Qin, Y.; Yang, H.; Zhang, S.; Liu, X.; Luo, J. Hollow CoFe-layered double hydroxide polyhedrons for highly efficient $\mathrm{CO}_{2}$ electrolysis. Sci. China Mater. 2021, 65, 536-542. [CrossRef]

43. Gao, Y.; Mi, L.; Wei, W.; Cui, S.; Zheng, Z.; Hou, H.; Chen, W. Double metal ions synergistic effect in hierarchical multiple sulfide microflowers for enhanced supercapacitor performance. ACS Appl. Mater. Interfaces 2015, 7, 4311-4319. [CrossRef]

44. Zhang, G.-Q.; Li, B.; Liu, M.-C.; Yuan, S.-K.; Niu, L.-Y. Liquid phase synthesis of CoP nanoparticles with high electrical conductivity for advanced energy storage. J. Nanomater. 2017, 2017, 9728591. [CrossRef]

45. Yang, Q.; Wang, D.; Wang, C.; Li, X.; Li, K.; Peng, Y.; Li, J. Facile surface improvement method for LaCoO 3 for toluene oxidation. Catal. Sci. Technol. 2018, 8, 3166-3173. [CrossRef]

46. Ren, J.-T.; Yuan, Z.-Y. Bifunctional electrocatalysts of cobalt sulfide nanocrystals in situ decorated on N, S-codoped porous carbon sheets for highly efficient oxygen electrochemistry. ACS Sustain. Chem. Eng. 2019, 7, 10121-10131. [CrossRef] 
47. Song, H.; Zhang, F.; Song, H.; Xu, X.; Li, F. The effect of neodymium content on dibenzothiophene HDS performance over a bulk $\mathrm{Ni}_{2} \mathrm{P}$ catalyst. Catal. Commun. 2015, 69, 59-62. [CrossRef]

48. Dutta, S.; Indra, A.; Feng, Y.; Song, T.; Paik, U. Self-supported nickel iron layered double hydroxide-nickel selenide electrocatalyst for superior water splitting activity. ACS Appl. Mater. Interfaces 2017, 9, 33766-33774. [CrossRef]

49. Peck, M.A.; Langell, M.A. Comparison of nanoscaled and bulk NiO structural and environmental characteristics by XRD, XAFS, and XPS. Chem. Mater. 2012, 24, 4483-4490. [CrossRef]

50. Yin, J.; Li, Y.; Lv, F.; Lu, M.; Sun, K.; Wang, W.; Wang, L.; Cheng, F.; Li, Y.; Xi, P.; et al. Oxygen Vacancies Dominated NiS $2 /$ CoS $_{2}$ Interface Porous Nanowires for Portable Zn-Air Batteries Driven Water Splitting Devices. Adv. Mater. 2017, $29,1704681$. [CrossRef] [PubMed]

51. Wu, J.; Ma, L.; Yadav, R.M.; Yang, Y.; Zhang, X.; Vajtai, R.; Lou, J.; Ajayan, P.M. Nitrogen-Doped Graphene with Pyridinic Dominance as a Highly Active and Stable Electrocatalyst for Oxygen Reduction. ACS Appl. Mater. Interfaces 2015, 7, 14763-14769. [CrossRef]

52. Sheng, Z.-H.; Shao, L.; Chen, J.-J.; Bao, W.-J.; Wang, F.-B.; Xia, X.-H. Catalyst-Free Synthesis of Nitrogen-Doped Graphene via Thermal Annealing Graphite Oxide with Melamine and Its Excellent Electrocatalysis. ACS Nano 2011, 5, 4350-4358. [CrossRef]

53. Wang, X.; Zhu, H.; Yang, C.; Lu, J.; Zheng, L.; Liang, H.-P. Mesoporous carbon promoting the efficiency and stability of single atomic electrocatalysts for oxygen reduction reaction. Carbon 2022, 191, 393-402. [CrossRef]

54. Liang, H.-W.; Zhuang, X.; Brüller, S.; Feng, X.; Müllen, K. Hierarchically porous carbons with optimized nitrogen doping as highly active electrocatalysts for oxygen reduction. Nat. Commun. 2014, 5, 4973. [CrossRef] [PubMed]

55. Li, M.; Wang, C.; Hu, S.; Wu, H.; Feng, C.; Zhang, Y. Nitrogen, phosphorus co-doped mesoporous carbon materials as efficient catalysts for oxygen reduction reaction. Ionics 2019, 25, 4295-4303. [CrossRef] 